\title{
Dialogue as a Strategy of Struggle: Religious Politics in East Germany, 1957-1968
}

\author{
Heléna Tóth \\ History Department, Otto-Friedrich-University, Fischstrasse 5/7, 96047 Bamberg, Germany \\ helena.toth@uni-bamberg.de
}

\begin{abstract}
This article argues that the topos of dialogue between Christians and Marxists fulfilled a key role in the creation and maintenance of power relations in religious politics in East Germany. Three case studies illustrate the topos of dialogue as a strategy of struggle: 1 . the campaign against 'revisionism' and 'politicised religion'; 2. the church policy strategy of 'differentiation'; 3 . the critique of the phenomena commonly associated with the Christian-Marxist dialogue outside East Germany in the mid-1960s. These instances of socialist religious politics, while having their own dynamics, were closely related through specific actors and argumentative strategies.
\end{abstract}

In 1990, one year after the fall of the Berlin Wall, long-time editor of the Journal of Ecumenical Studies (JES), Leonard Swidler, took stock of the history of the Christian-Marxist dialogue as a long tradition with renewed political relevance. Swidler believed that the rapidly changing tectonics of global politics made a historical overview necessary: as 'today the two Communist giants, the USSR and China, are in a variety of ways opening themselves up to dialogue and cooperation with many of their erstwhile enemies, including Christianity'. Together with the co-editor of JES, Paul Mojzes, ${ }^{2}$ Swidler had been a participant and a facilitator of dialogue between Christians and Marxists for decades. Based on his long experience, Swidler argued that an awareness of the historical dimension of the dialogue was a necessary foundation for the future: 'the recent revival of the Christian-Marxist dialogue is hopeful, and we very much need this hope, for the long-run alternative to it is the courting of future disaster. ${ }^{3}$ According to Swidler, the de-Stalinisation of Eastern Europe, the pontificate of Pope John XXIII and the Second Vatican Council created conditions that enabled Christian-Marxist dialogue to 'break out' in 1964 'almost simultaneously in a number of European countries: Czechoslovakia, Italy, West Germany, and France'. ${ }^{4}$ With regard to the Christian-Marxist dialogue, Swidler divided the states within the Soviet sphere of influence into three groups: 1. Czechoslovakia, Hungary and Yugoslavia, where 'true dialogue' could develop, even if only for brief periods of time; 2. Poland, where the dialogue was 'carefully managed ... in order to facilitate cooperation in recognition of each other's strength' and 3. the Soviet Union, Bulgaria, Rumania and East Germany, where 'no dialogue

1 Leonard Swidler, 'Christian-Marxist Dialogue: An Uneven Past - A Reviving Present - A Necessary Future', The Journal of Peace and Justice Studies, 2, 2 (1990), 29-59, 29. Swidler has often reprised this narrative since then, most recently in Leonard Swidler, The Age of Global Dialogue (Eugene, OR: Pickwick Publications, 2016).

2 Among others, see Paul Mojzes: Varieties of Christian-Marxist Dialogue (Philadelphia: The Ecumenical Press, 1978) or Paul Mojzes, Church and State in Postwar Eastern Europe: A Biographical Survey (New York: Greenwood Press, 1987).

3 Swidler, 'Christian-Marxist Dialogue', 29.

4 Ibid. Most recently about the effects of Vatican II in Eastern Europe, see Piotr H. Kosicki, Vatican II Behind the Iron Curtain (Washington D.C.: Catholic University of America Press, 2016).

(c) The Author(s) 2020. This is an Open Access article, distributed under the terms of the Creative Commons Attribution licence (http://creativecommons.org/licenses/by/4.0/), which permits unrestricted re-use, distribution, and reproduction in any medium, provided the original work is properly cited. 
has ever existed'. ${ }^{5}$ While Swidler painted the origins of the Christian-Marxist dialogue with fairly broad strokes, he offered a framework for connecting various attempts at crossing ideological divides on both sides of the Iron Curtain. In his understanding specific political constellations, such as the liberalisation of Czechoslovak society between 1965 and 1967, created a space for encounters between Christian and Marxist thinkers, and while he did not offer an explanation for the absence of dialogue in other states, he implied that it was the lack of those conditions.

Swidler used the East German example as a contrast to demonstrate the extent to which ChristianMarxist dialogue was possible in phases of liberalisation elsewhere in the Eastern Bloc. A research project on the legacy of the forced secularisation processes in the former East Germany conducted in the early 2000s went even further and identified the state's ability to maintain and cultivate the ideological divide between Christianity and socialism as one of its fundamental characteristics and remaining legacies. Monika Wohlrab-Sahr, Uta Karstein and Thomas Schmidt-Lux were looking to explain the absence of religious revival in the decades following the fall of communism despite the enormous significance of religious actors, specifically the Protestant Church, in the peaceful revolution. ${ }^{6}$ Based on interviews conducted with twenty-four families across three generations, the authors focused on the discursive framing of secularity and found that 'through repression but also through persuasion [East Germany] managed to install the perspective of a basic conflict between religion and politics as well as between religion and science, which we find in the narratives and arguments of East German interviewees until today'. Broadly speaking, the authors argued that the Socialist Unity Party (Sozialistische Einheitspartei Deutschlands; SED) created and maintained a discourse of polarisation, drawing clear borders 'between membership in the church or in the party, between a religious and a scientific worldview and between Christian ethics and morality [pitted] against a socialist hyper-morality'. ${ }^{8}$ These dichotomies, the authors found, initially imposed on the population, were internalised in time and became 'part of their subjective reality and are reproduced to the present day. ${ }^{9}$

Based on Swidler's typology and Wohlrab-Sahr's findings, it is not immediately apparent how East Germany fits into this special issue on the diversity of the Christian-Marxist dialogue in the 1960s, where individual articles examine various facets of convergence, encounters and conversations taking place in a broad array of loci, ranging from the construction of political biographies to formulating party programmes, from discussions among the laity to controversies within the ranks of major church organisations. In fact, even the only book-length study of the Christian-Marxist dialogue in East Germany, Simone Thiede's 1998 dissertation, albeit strongly nuances, does not entirely negate those conclusions. ${ }^{10}$ Thiede argues that repressive church politics combined with the perceived

5 Ibid. Swidler's co-editor at the Journal of Ecumenical Studies Paul Mojzes developed a different typology for the Christian-Marxist dialogue: 1. Total absence of dialogue and annihilation of churches by the communist government (Area Wide, Albania); 2. Avoidance of dialogue: coexistence and political accommodation leading to limited cooperation (the Soviet Union, Bulgaria, Romania); 3. The practice of dialogue despite official disclaimers (East Germany); carefully managed dialogue in order to facilitate cooperation; recognition of each other's strength (Hungary, Poland, International Peace Symposia); critical involvement in dialogue; pluralism of expectations and attitudes (Czechoslovakia, Yugoslavia, Paulus-Gesellschaft international congresses). Paul Mojzes, Christian-Marxist Dialogue in Eastern Europe (Minneapolis: Augsburg Publishing House, 1981), 35-164. Mojzes cited Johannes Hammel, Heino Falcke, Heinrich Gruber, Carl Ordnung, Elizabeth Adler and Günther Jacobs as representatives of a dialogue between Christians and Marxists. Mojzes, Dialogue, 55.

6 Monika Wohlrab-Sahr; Uta Karstein; Thomas Schmidt-Lux, Forcierte Säkularität: Religiöser Wandel und Generationendynamik im Osten Deutschlands - Zur Logik der Aneignung forcierter Säkularisierung (Frankfurt; New York: Campus Verlag, 2009).

7 Ibid., 350.

8 Mathias Rohe, Havva Engin, Mouhanad Khorchide, Ömer Özsoy and Hansjörg Schmid, eds., Christentum und Islam in Deutschland. Grundlagen, Erfahrungen und Perspektiven des Zusammenlebens. Vol. 1 (Freiburg im Breisgau: Verlag Herder, 2014), 63.

9 Wohlrab-Sahr et.al, Forcierte Säkularität, 295.

10 Simone Thiede, Der Dialog zwischen Religionen und säkularen Weltanschauungen dargestellt am Beispiel des christlichmarxistischen Dialogs in der DDR (Frankfurt am Main: Peter Lang, 1999). 
anti-communist agenda of the global Christian-Marxist dialogue made dialogue impossible in East Germany in the 1960s. In the following decades, Thiede continues, and certainly by the mid-1980s, a network of researchers working on the sociology of religion and Protestant church actors emerged, however, whose encounters on the local level grew into a series of conferences in Güstrow, Berlin and Bad Saarow. ${ }^{11}$ Despite the state's opposition to such organised initiatives, and while both sides carefully avoided using the term dialogue, these interactions in effect amounted to a sustained exchange of ideas. The impact of these conversations remained limited to a small circle of intellectuals, Thiede concedes, but she argues that in the last decade of East Germany's existence a Christian-Marxist dialogue did exist, even if it had not before. ${ }^{12}$

The goal of this article is not to uncover hitherto unknown instances of Christian-Marxist dialogue in East Germany, nor to treat the country as a mere example for the absence of a phenomenon. Rather, the following case studies consider the uses of the topos of the dialogue as a strategy of religious politics in the 1960s. The analysis centres around a phenomenon that the figures we commonly associate with the Christian-Marxist dialogue, and whom Swidler and Thiede had in mind in their analysis, would distance themselves from. For Erich Kellner, the founder of the Paulus Society, and Karl Rahner, Jesuit theologian and editor of the Internationale Dialog Zeitschrift, both protagonists and key facilitators of the Christian-Marxist dialogue in the 1960s, a core characteristic of the conversation across ideological divides was that it was not politised. As Kellner wrote: dialogue could not be 'a matter of politics, a tactic or a method, only a question of science and humanity. ${ }^{13}$ In this interpretation, the dialogue, which brought together scientists and Marxist philosophers, as well as Protestant and Catholic theologians, was framed as an alternative both to religious politics and to what Jan Milič Lochman, Protestant theologian from Czechoslovakia, termed 'politicised theology'. ${ }^{14}$ The purpose of the conversation was not to enter into polemics nor to inform political action on either side but to identify (or develop) 'core positions' that emphasised commonalities between Christianity and Marxism. ${ }^{15}$ A corollary of liberating dialogue from the constraints of its immediate political constellations was shifting the focus away from the 'realities of socialism in power'. ${ }^{16}$ This article turns the perspective around. It argues that, in the East German case, the topos of dialogue between Christians and Marxists fulfilled a central role in the creation and maintenance of power relations in religious politics and was used to buttress the dualistic view of politics and religion that sociologists of religion could still detect decades after the fall of the Berlin Wall. ${ }^{17}$

Focusing on the period between 1957 and 1968, three case studies illustrate the SED's use of the topos of dialogue as a strategy of struggle: 1. the campaign against 'revisionism' and 'politicised religion' starting around 1956-7; 2. the church policy strategy of 'differentiation' enfolding around the same time; 3. the critique of the phenomena commonly associated with the Christian-Marxist dialogue (the consequences of the Second Vatican Council, the work of the Paulus Society, etc.) in the mid-1960s. These instances of socialist religious politics cover almost a decade, and while they have their own dynamics, they are closely related through specific actors. In each case, the topos of dialogue performed a distinct function within a larger argumentative structure: first it was used to conceptualise

11 A list of conferences in Thiede, Der Dialog in $\operatorname{der} D D R, 93-5$; for a list of research centres involved in the dialogue, Ibid., 288-9.

12 Thiede argues explicitly against Swidler and Mojzes, Thiede, Der Dialog in der DDR, 260-9.

13 Quoted in Pascal Eitler, 'Politik und Religion: Semantische Grenzen und Grenzverschiebungen in der Bundesrepublik Deutschland 1965-1975', in Ute Frevert and Heinz-Gerhard Haupt, eds., Neue Politikgeschichte. Perspektiven einer historischen Politikforschung (Frankfurt; New York: Campus Verlag, 2005), 268-303. Also Christian A. Widmann, 'Vom Gespräch zur Aktion? Der "christlich-marxistische Dialog” und die Politisierung des Protestantismus in den 1960er und 70er Jahren', in Klaus Fitschen ed., Die Politisierung des Protestantismus: Entwicklungen in der Bundesrepublik Deutschland während der 1960er und 70er Jahre (Göttingen: Vandenhoeck \& Ruprecht, 2014), 121-49.

14 Eitler, 'Politik und Religion', 298.

15 Roland Boer, Red Theology: On the Christian Communist Tradition (Leiden: Brill, 2019), 119.

16 Boer, Red Theology, 124.

17 The article here follows Roland Boer's definition: 'More broadly, [the Christian-Marxist dialogue] may refer to anyone Marxist or Christian or both - who is engaged in some way with the two terms'. Ibid., 118. 
the methods of ideological adversaries, then deployed as a means of socialist apologetics and finally, it was presented as a phenomenon that East Germany was supposed to have transcended by the early 1960s.

To trace the shifts in the way political and religious actors understood and deployed dialogue as a political or argumentative strategy, the article combines a close reading of texts on atheism and the philosophy of religion with an analysis of shifts in church policy. Focusing on these sources might seem a somewhat odd choice. Most citizens of East Germany experienced the 'conflict between the religious and the scientific worldview' in more tangible and consequential forms. In 1957 the State Bureau for Church Affairs was set up, which oversaw and carried out a broad array of repressions against church members. ${ }^{18}$ Starting in 1958 the SED politicised everyday life in new ways with relation to religion: they relaunched the initially failed campaign of the Jugendweihe as a vehicle to compete against confirmation and to inculcate political loyalty in youth. ${ }^{19}$ Other socialist rites of passage followed: the socialist name giving ceremony, wedding and funeral. ${ }^{20}$ These rituals served as a public stage for practicing atheism. Textbooks for civics education in preparation for the Jugendweihe communicated to generations of East German citizens the state's narrative of the boundaries between worldviews. $^{21}$ The abstract and technical philosophical debates about the nature of bourgeois philosophy or about Marxism-Leninism's position on religion reached an incomparably smaller audience. It was, however, through these debates that the contours of ideology were drawn. As Norbert Kapferer has argued, since the 1950s the accents set by East German philosophy can be considered as reliable seismographs for shifts in the priorities of the agenda of the SED. ${ }^{22}$

\section{Dialogue as Transgression: The Method of the Enemy}

The Thirtieth Congress of the Central Committee of the SED in January and February 1957 marked the beginning of a new wave of atheistic propaganda in East Germany. ${ }^{23}$ While the SED had followed a consequent course since 1949 of undermining the position of the churches in public life, the preferred method of implementation had been the intimidation of the churches and their members rather than an engagement with the concept of religion. In response to Soviet critique of the political damages resulting from a repressive church policy, and in reaction to the June uprising in 1953, the SED published a position paper on 14 March 1954 identifying the 'political-ideological work of enlightenment' and atheistic education as the primary tools to fight 'religious worldview'. ${ }^{24}$ This policy, however, was

\footnotetext{
18 Bernd Schäfer, The East German State and the Catholic Church (London: Berghahn Books, 2010), 62-70. Armin Boyens, 'Das Staatssekretariat für Kirchenfragen', in Clemens Vollnhals, ed., Die Kirchenpolitik von SED und Staatssicherheit: Eine Zwischenbilanz (Berlin: Ch. Links Verlag, 1997), 120-38.

19 Albrecht Döhnert, 'Jugendweihe - Die Familie als Feld der SED-Kirchenpolitik', in Dieter Vorsteher, ed., Parteiauftrag: Ein neues Deutschland. Bilder, Rituale und Symbole der früher DDR (Berlin: Köhler and Amelang, 1996), 274-87; Hermann Wentker, 'Die Einführung der Jugendweihe in der DDR. Hintergründe, Motive und Probleme', in Hartmut Mehringer, ed., Von der SBZ zur DDR. Studien zum Herrschaftssystem in der Sowjetischen Besatzungszone und in der Deutschen Demokratischen Republik (München: Oldenburg, 1995), 139-65; Chauliac, Marina Chauliac: 'Die Jugendweihe' in Martin Sabrow, ed., Erinnerungsorte der DDR (München: Beck, 2009), 161-8.

20 In contrast to the Jugendweihe, which received significant political and infrastructural support, the introduction of other rites of passage was a more contingent process: Felix Robin Schulz, Death in East Germany (New York, London: Berghahn, 2013). On name giving ceremonies, see Georg Diederich, “'Die Mehrzahl steht im Bann der Kirche:” Die Einführung atheistischer Ersatzriten im Bezirk Rostock 1955’, Deutschland Archiv, 32, 1/3 (1999), 34-45; Heléna Tóth, “'Zwischen Gott und dem freien Gewissen ist für eine Staatsreligion kein Platz:” Die Namensweihe und politische Religion in der DDR', Geschichte und Gesellschaft, 45, 1 (2019), 37-69.

21 Anja Kirsch, Weltanschauung als Erzählstruktur. Zur Konstruktion von Religion und Sozialismus in Staatsbürgerkundenschulbüchern der DDR (Göttingen: Vandenhoeck \& Ruprecht, 2016).

22 Norbert Kapferer, Das Feindbild der Marxistisch-Leninistischen Philosophie in der DDR 1945-1988 (Darmstadt: Wissenschaftliche Buchgesellschaft, 1990), 155.

23 Schäfer, The East German State and the Catholic Church, 73.

24 Erhart Neubert, 'Kirchenpolitik', in Matthias Just, ed., DDR-Geschichte in Dokumenten. Beschlüsse, Berichte, interne Materialien und Alltagszeugnisse, (Berlin: Links Verlag, 1997), 363-430.
} 
not implemented consistently. To return to the Jugendweihe, the socialist alternative to confirmation, as an example: the tradition of this rite of passage reached back to the free-thinkers and the workers' movement in the nineteenth century but had been banned since 1949, as a result of the SED's reluctance to open a front against the churches in the area of rituals. In the wake of the 1954 shift in religious policy, the Jugendweihe was introduced again, but schools were allowed agency in determining how and to what extent they persuaded their students to participate. ${ }^{25}$ It was only after the atheistic propaganda was relaunched in 1957 that the Jugendweihe, with the personal support of Walter Ulbricht, received the concentrated state support that turned it into one of the most emblematic embodiments of state ideology in everyday life.

The driving force behind the renewed atheist propaganda were the shifting tectonics of power relations within the Soviet sphere of influence and the ranks of the SED. The Twentieth Congress of the Communist Party in the Soviet Union in February 1956 triggered discussions about the legacy of Stalinism across the Eastern Bloc, including in East Germany. The concentrated effort to (re)set ideological boundaries led to a power struggle within the SED. On the question of religion, the Central Committee of the SED was split into two camps: the 'materialist-atheist line', including Ulbricht himself, comprised those who proposed strong anti-religious propaganda, and the 'socialist patriotic' line, whose representatives focused not on the conflict between worldviews but on creating a united front in the service of building socialism. ${ }^{26}$ Ulbricht's victory within the SED was accompanied by the founding of the State Office of Church Affairs, which coordinated a concentrated attack on churches and on religion. ${ }^{27}$

A two-pronged strategy complemented the work of the State Bureau of Church Affairs and the increased emphasis on atheist practices in everyday life. One component of this new approach was investment into relevant academic fields. Research on atheism received state support as an area within the sociology of religion and attempts were made to establish it as a separate subject with corresponding academic infrastructure. ${ }^{28}$ The second component was the public demonstration of the boundaries between worldviews. Starting in 1957 two controversies in particular embodied this new line in religious policy: the marginalisation of Ernst Bloch and a concentrated attack on neothomism. The topos of dialogue between Christianity and Marxism was used in both cases as means to frame ideological enemies, albeit in two different ways: in Bloch's case, the charge centred around Christianity creeping into his philosophy, while neothomist philosophers challenged the authority of interpretation over the Marxist canon.

Ernst Bloch had been one of the most prominent and internationally respected philosophers working in East Germany in the late 1950s. ${ }^{29}$ His marginalisation was a complex process, in which university politics at the Karl-Marx University in Leipzig, which sought to stamp out critique against the SED in the wake of Ulbricht's victory in the internal power struggle, and the campaign against 'revisionism' in the Soviet sphere of influence, played just as important roles as the specific philosophical principles in which Bloch's public castigation was framed. ${ }^{30}$ In socialist parlance the term 'revisionism'

${ }^{25}$ Georg Diederich and Bernd Schäfer, 'Religiöses Brauchtum und kirchliches Leben im Alltag der DDR - zwischen Anfechtung und Behauptung', in Landtag Mecklenburg-Vorpommern, ed., Schriftenreihe der Enquete-Kommission 'Aufarbeitung und Versöhnung', vol. VI. (Schwerin: Landtag Mecklenburg-Vorpommern, 1997), 165-8.

26 Schäfer, The East German State and the Catholic Church, 74.

27 Andreas Malycha, Peter Jochen Winters, Die SED. Geschichte einer deutschen Partei (München: Beck, 2009), $139-47$.

28 Dirk Schuster, 'Das Postulat vom baldigen Ende der Religion. Die DDR-Religionssoziologie über eine Zukunft ohne Gott', in Dominik Groß and Klaus Freitag, eds., Zurück in die Zukunft? Die Bedeutung von Diskursen über 'Zukunft' in der Wissenschaftsgeschichte (Kassel: university press, 2017), 94.

29 For an overview of the institutional history of philosophy in West Germany: Hans-Christoph Rauh, Philosophie aus seiner abgeschlossenen Welt. Zur Geschichte der DDR-Philosophie und ihrer Institutionen (Berlin: Ch. Links Verlag, 2017).

30 For a detailed account on the campaign against Ernst Bloch: Guntolf Herzberg, Anpassung und Aufbegehren: die Intelligenz der DDR in den Krisenjahren 1956/58 (Berlin: Ch. Links Verlag, 2006), 511-38. The other main target of the revisionist campaign was György Lukács, a close friend of Bloch's since before the First World War. See Werner Jung, 'The Early Aesthetic Theories of Bloch and Lukács', New German Critique, 452 (1988), 41-54. 
denoted in general the corruption of supposedly clean Marxist thought with 'bourgeois' ideas. ${ }^{31}$ In Bloch's case, the charge centred around the religious elements of his philosophy. The power of religious ideas in revolutionary movements and the revolutionary potential of religion had been at the heart of Bloch's work since The Spirit of Utopia (1917) and Thomas Müntzer: The Theologian of Revolution (1921). ${ }^{32}$ Utopian elements in social movements represented the core theme also in Bloch's last major work before the 'revisionist campaign', the first volume of the Principle of Hope (1955). In a review published the same year, Hans Heinz Holz, a doctoral student of Bloch, had praised his advisor for conceptualising hope as a bridge 'between subjectivity and material being' and for connecting 'hope, the analysis of the concept of hope and revolutionary action'. ${ }^{33}$ Writing in the journal of the Academy of Sciences, Holz had concluded that 'the philosophy of hope is in fact the unfolding and development of the philosophical core idea of Marxism'. ${ }^{34}$ Barely two years later precisely those aspects of Bloch's philosophy of hope that Holz had praised were used as evidence for his supposed 'revisionism'. Bloch lost his academic position, and his students, who shared his political views and activism, also suffered the consequences. Some, like Holz, experienced setbacks in their academic careers, others went to prison. ${ }^{35}$

Of course, it was not only, or not even primarily, the complexities of Bloch's philosophy that made him a target of attack for the SED. After the June uprising in 1953 Bloch had still passionately defended East Germany in his 'letter to humanists' as a place for free thinking, musing about the nature of truth referencing Spinoza and Thomas Aquinas - references that soon became unpublishable. ${ }^{36}$ Bloch considered openness towards ideological opponents as a sign of strength. As he pronounced at a congress of the Academy of Sciences in March 1956: open engagement with Western philosophy 'is no longer the attitude of a gouvernante, afraid that toddler Marxism (Kindchen Marxismus) will make one of his ribbons dirty. It is rather the attitude of an intellectual great power that has arrived: the freshness and boldness of a world in ascent'. ${ }^{37}$ That Bloch's speech was not published in the conference proceedings was a direct result of the enfolding events in 1956. Bloch's critique of Ulbricht's version of the personality cult and his reaction to the uprisings in Poland and Hungary widened a rift between him and the emerging class of 'cadre philosophers', who were to provide the ideological foundations for the renewed campaign against religion. ${ }^{38}$

31 Malycha, Die SED. Geschichte einer deutschen Partei, 126-38.

32 Günter Vogler, 'Ernst Bloch und Thomas Müntzer. Historie und Gegenwart in der Müntzer-Interpretation eines Philosophe', in Norbert Fischer and Mariam Kobelt-Groch, eds., Außenseiter zwischen Mittelalter und Früher Neuzeit (Leiden: Brill, 1997), 243-7. See also Arno Münster, Utopie, Messianismus und Apokalypse im Frühwerk von Ernst Bloch (Frankfurt am Main: Suhrkamp, 1982).

33 Hans Heinrich Holz, 'Der Philosoph Ernst Bloch und sein Werk “Das Prinzip Hoffnung”. Ernst Bloch zum siebzigsten Geburtstag', Sinn und Form. Beiträge zur Literatur, 7, 3 (1955), 446, 431.

34 Holz, 'Der Philosoph Ernst Bloch und sein Werk', 446. On the controversial position of Sinn und Form as an academic journal in East Germany see Matthias Braun, Die Literaturzeitschrift Sinn und Form. Ein ungeliebtes Aushängeschield der SED-Kulturpolitik (Bremen: Edition Temmen, 2004).

35 Hans Heinz Holz came to East Germany to study with Ernst Bloch after his first dissertation in Mainz was rejected because of university politics. After Bloch's marginalisation, Holz returned to the Federal Republic of Germany and worked as a journalist. His dissertation was accepted in Leipzig in 1969, which enabled Holz to pursue an academic career in Marburg. Holz's example shows that institutional politics and ideology could play significant but not always equally important roles in shaping academic biographies. On the controversy that ensued about Holz's doctoral title, see Hans Mayer, Bloch's former colleague from Leipzig: 'Ein Doktortitel vor Gericht. In Sachen Dr. Günter Zehm gegen Dr. Hans Heinz Holz', Die Zeit, 3 Nov. 1972, 12-5.

36 Ernst Bloch, 'Zum Gremium der Humanisten', Aufbau. Kulturpolitische Monatsschrift, 10, 1 (Jan.1954), 10-1.

37 Ernst Bloch, 'Schlußwort auf dem Kongreß der Deutschen Akademie der Wissenschaften, Berlin, Schichten der Freiheit betreffend', Ernst Bloch, Gesamtausgabe, vol. 11 (Frankfurt. a. M: Suhrkamp, 1977), 366.

38 Norbert Kapferer uses the term 'cadre philosophers' to describe the group of philosophers who carried out the 'revisionist campaign' and helped formulate and implement the ideological hard line from 1956 to 1961. The term is controversial. Kapferer's critics accused him of reading sources reductively, out of context. His critics make a valid point that it would be a mistake to reduce an entire academic discipline to an ideological executive branch of the SED, and it is also an oversimplification to equate Marxist thought with the small but vocal choir of ideological hard-liners. With reference to the atheist propaganda, however, the source base of this article seems to confirm Kapferer's analysis. The critical reviews of 
Bloch's fate was sealed after the arrest and trial of his publisher and colleague, Wolfgang Harich, editor at the Aufbau Verlag, who had published a 'platform about the specifically German way to socialism'. Bloch's involvement in the circles around Harich was clear. Starting with an open letter in Neues Deutschland in December 1956, Bloch's entire work, including his habitus as a scholar, came under criticism. $^{39}$

The author of the letter was Bloch's colleague and long-time critic, professor for dialectical and historical materialism, Rugard Otto Gropp. Gropp had spoken out against Bloch's utopian philosophy already back in 1954, in the wake of the first wave of the atheist campaign; but while Bloch's political position was stable, the critique had had no major effect. In the changed political constellations, however, most likely directly commissioned by the SED, Gropp launched his attack in the largest press organ of East Germany. ${ }^{40}$ Gropp centred his critique around Bloch's concept of hope, 'a subordinate [phenomenon] belonging to the realm of the psyche' that Bloch tried to turn into a 'world principle'. ${ }^{41}$ A few months later Gropp went even further and called Bloch's philosophy an 'anti-Marxist theory of redemption'. ${ }^{42}$ The supposedly religious qualities of Bloch's texts soon crystallised as the main focus of the critique: Johannes Heinz Horn, a logician, Bloch's colleague and the party secretary at the Institute for Philosophy, mused about 'how much Judeo-Christian eschatology or how much Judeo-Christian chiliasm combined with elements of early Marxism' made it into Bloch's philosophy and concluded that it must be enough for readers in the West to argue that Marxism was a form of religion itself. ${ }^{43}$ Even worse, Horn, argued, 'what Bloch understands under Marxism and what he declared as a philosophy of hope is indeed a religion, even if one without God'. ${ }^{44}$ The concentrated attacks forced Bloch into voluntary early retirement from Leipzig in 1957 but did not interrupt his work. Bloch moved to West Germany in 1961 and became an emblematic albeit controversial participant in the MarxistChristian dialogue, through Philosophy of Hope and through his last major book, Atheism in Christianity (1968).

The conservative Marxist critique of Bloch's work was more complex than mere attempts to reduce his philosophy to a (pseudo-)religion or cast him as a charismatic, religious cult-figure. ${ }^{45}$ For the purposes of this article, however, it is significant that from the various discursive possibilities for framing 'revisionism' as an ideological heresy, the main line of criticism focused on casting Bloch's philosophy as religion. The boundaries of ideological orthodoxy were drawn or sharpened on a frontline between worldviews.

The debate about the religious elements in Bloch's work was arguably embedded in a broader attack on so-called 'politicised religion' and 'reactionary clericalism'. For all their differences - in one case the removal of a revered university professor from his position, in the other a campaign against the political dimensions of religion and theology - the two campaigns overlapped not only chronologically but also through their participants: it was some of Bloch's most outspoken critics, Johannes Heinz Horn, Hermann Ley and Manfred Buhr, who spearheaded the shift towards identifying politicised religion and, in particular, neothomist philosophy as the most dangerous enemies of socialism. ${ }^{46}$ Just as

Kapferer's book and his answer: Norbert Kapferer, Innenansichten ostdeutscher Philosophen (Berlin: Wissenschaftliche Buchgesellschaft, 1994); also on Kapferer's interpretation: Stefania Maffeis, Zwischen Wissenschaft und Politik. Transformationen der DDR-Philosophie, 1945-1993 (Frankfurt; New York: Campus Verlag, 2007), 27-32.

39 Rugard Otto Gropp, 'Idealistische Verirrungen unter “antidogmatischen” Vorzeichen', Neues Deutschland, 19 Dec. 1956, 4.

40 Arno Münster, Ernst Bloch. Eine politische Biographie (Berlin: Philo, 2004), 281.

41 Gropp, 'Idealistische Verirrungen', 4.

42 Rugard Otto Gropp, 'Ernst Blochs Hoffnungsphilosophie - eine antimarxistische Welterlösungslehre', in Heinz Johannes Horn, ed., Ernst Blochs Revisionismus: Kritische Bemerkungen marxistischer Wissenschaftler mit Blochschen Philosophie (Berlin: Dt. Verlag d. Wiss., 1957), 9-49.

43 Heinz Johannes Horn, 'Kritische Bemerkungen zur Philosophie Ernst Blochs', in Horn, Ernst Blochs Revisionismus, 250.

44 Ibid.

45 See Gropp's book-length refutation. The title Mystical Philosophy of Hope is Incompatible with Marxism summarised the argument: Mystische Hoffnungsphilosophie ist unvereinbar mit Marxismus (Berlin: Verlag Junge Welt, 1957).

46 The motivations of the campaign's participants varied widely. Some acted out of conviction, others were pressured into joining in. When Johannes Heinz Horn committed suicide in the spring of 1958, his colleagues believed that it was the 
with Bloch's marginalisation, the roots of the campaign against 'reactionary clericalism' also reached back to Ulbricht's reassertion of power within the SED. Already in 1956 the Central Committee declared war on what they termed an 'ideology of crusade'. ${ }^{47}$ While the term 'reactionary clericalism' belonged to the classical vocabulary of ideological struggle in the communist tradition, in 1956-7 it referred primarily to the political role of organised religion in West Germany. The churches' support for West Germany's remilitarisation and NATO membership, as well as the perceived Catholic influence on Konrad Adenauer, stood at the centre of what the SED considered a new 'crusade' against socialism in general and specifically against East Germany.

For the SED a significant impulse to extend the political fight specifically into the arena of philosophy came from a talk by Teodor Ilyich Oizerman, a prominent historian of philosophy at the University Moscow, delivered to the Central Committee of the SED in $1957 .{ }^{48}$ Oizerman's topic was contemporary currents in bourgeois philosophy as the antithesis to Marxist thought. The term bourgeois philosophy included a broad range of philosophical positions, but Oizerman singled out neothomism as the strongest influence. He argued that 'the demasking of the reactionary content [of neothomism] is one of the seminal philosophical tasks in all countries. This is especially true for countries with significant Catholic populations, such as Germany and France'. ${ }^{49}$ Neothomism had been introduced as the official philosophy of the Catholic Church in 1879 by Leo XIII in Aeterni Patris. With a new edition of Thomas Aquinas's works and the establishment of a Dominican University 1895, Leo XIII laid the intellectual and institutional foundations upon which neothomism became the most important philosophical school within the Catholic Church until the Second Vatican Council. Despite its institutionally privileged position, the meaning and the function of neothomism had been passionately debated in Catholic circles, but Pius XII re-established it as a church doctrine in his 1950 encyclica Humani generis. From the perspective of the SED in 1957, therefore, neothomism was the official doctrine of the Catholic Church, recently reaffirmed by the same pope who in his 1949 'Decree against Communism' threatened Catholics with excommunication if they cooperated with communist parties.

When Oizerman identified neothomism as a principal enemy of Marxist thought, he and his audience had not only the political role of the Catholic Church in mind but also specific authors who had been engaging with the Marxist canon for decades. ${ }^{50}$ One such author was Gustav Wetter. ${ }^{51}$ Wetter, a Jesuit priest and director of the Collegium Russicum in Rome, had worked for decades on Marxist philosophy. He had published his lectures in Italian (1948) and German (1952), and the latter included a detailed analysis of Stalin's 1950 letter to the linguists and its implications for contemporary

direct or indirect result of the pressures of the previous months. Philipp McKnight, 'Geschichte und DDR-Literatur (Amnesie, Fragmentierung, Chronik, Kritisches Bewußtsein und Weichenstellung im Rückblick auf die Mitte der 50er Jahre: Mankurt, Horn und Horns Ende)', in Hans-Christian Stillmark and Christoph Lehker, eds., Rücblicke auf die Literatur der DDR (Amsterdam; New York: Rodopi, 2002), 209.

47 Kapferer, Das Feindbild, 173.

48 In German the transliteration is Oiserman. Teodor I. Oiserman, Die Hauptströmungen der bürgerlichen Gegenwartsphilosophie (Berlin: Dietz Verlag, 1958), 14.

49 Ibid.

50 One case in point was the Dominican priest and Freiburg university professor, Josef M. Bocheński and his role in the process that led to the ban of the Communist Party in West Germany in 1956. In his position paper 'Communism and the Dignity, Freedom and Equality in the Interpretation of the Basic Law' Bocheński argued that the Communist Party's and the Basic Law's understanding of these key concepts were fundamentally incompatible, and developed a theory of 'immunisation' which supposed to protect West German citizens against Communist ideology. Rüdiger Thomas, 'Zur Auseinandersetzung mit dem deutschen Kommunismus in der Bundeszentrale für Heimatdienst. Eine kritische Sondierung im Umfeld des KPD-Verbots', in Stefan Creuzberger and Dierk Hoffmann, eds., 'Geistige Gefahr' und 'Immunisierung der Gesellschaft'. Antikommunismus und politische Kultur in der frühen Bundesrepublik (München: Oldenburg, 2014), 133-9.

51 Gustav Wetter also played a role in the preparation of the ban on the communist party in West Germany. Joseph Wintrich, the ruling judge, used Wetter's lectures in Salzburg as preparation for formulating his decision: Michael Stolleis, Geschichte des öffentlichen Rechts in Deutschland, vol. 4 (München: C.H. Beck, 2017), 152. 
Soviet philosophy. ${ }^{52}$ Wetter was not the first neothomist philosopher to offer an extensive analysis of dialectical materialism in German. ${ }^{53}$ What set his work apart was an extensive source base and his ability to combine a detailed historical overview of the concept of dialectical materialism from the nineteenth century onwards with an analysis of its key concepts, a discussion of new developments in Soviet philosophy regarding science, as well as a more general reflection on the method of argumentation. Wetter's book represented the most complete neothomist response to Marxism to date and in 1956 a new edition was published precisely at the time when the SED was turning its attention towards politicised religion and neothomism. Even his critics in East Germany, notably professor for dialectical and historical materialism at the University of Jena, Georg Klaus, remarked that Wetter's book was based on an extensive study of the sources and that it must be emphasised that this author builds his polemic more skilfully ... against materialism than we are used to in the newspapers, journals, brochures, etc. of the [clerical] reaction in the last years'. ${ }^{54}$

The core element of Wetter's book that makes it relevant for this article was his argument about the intersections between dialectical materialism and thomism. As Klaus formulated: Wetter 'does not simply reject the dialectic, but he acknowledges it in many points, albeit only to emphasise that the theses of dialectic that he considers correct could be found already in [the works of] Thomas Aquinas'. ${ }^{55}$ Wetter's argument functioned on several levels. First, it argued that Soviet philosophy seemed to function as a state religion, a point that did not escape the attention of Wetter's readers on both sides of the Iron Curtain. As one reviewer noted: 'there is little need to point out that dialectic materialism as the state philosophy, not to say state religion of the Soviet Union, is a subject of great current interest'. ${ }^{56}$ Second, Wetter argued that the relationship of Marxists to Marxism could be characterised in religious terms: 'the militant Marxist draws from his faith in this doctrine his confidence that his subjective acts are connected to the secret powers of reality, a confidence that represents the secret of his force'. ${ }^{57}$ Third, Wetter argued that there were specific similarities between the (neo)scholastic and dialectic materialist way of argumentation: such as taking the classics as a starting point for developing responses to contemporary issues especially in the area of science, the critique of idealism and an epistemological emphasis on realism. Wetter even argued that there were similarities between dialectic materialism and the thomist theory of act-potency. ${ }^{58}$ For Wetter, the emphasis on the religious characteristics of Marxism and the similarities between (neo)thomist and dialectic materialist ways of argumentation set up a broader argument about true and false faith: Wetter ended his book with a vision of Catholic universalism, which would end the 'endless suffering' that communism had brought into the world.

Examining the religious roots of Marxism was not unique to Catholic theologians or philosophers. In an 1954 essay collection published by the study group of the Protestant academies, both philosopher Erwin Metzke and Protestant theologian Heinz-Dietrich Wendland explored the connection

52 Gustav Wetter, Il materialismo dialettico sovietico (Torino: G. Einaudi, 1948).

53 Bocheński published The Soviet-Russian Dialectic Materialism already in 1950: Die Sowjetrussische dialektische Materialismus (Bern: A. Francke, 1950).

54 Georg Klaus, Jesuiten, Gott, Materie. Des Jesuitenpaters Wetter Revolte wider Vernunft und Wissenschaft (Berlin: Deutscher Verlag der Wissenschaften, 1957), 22. Based on Klaus's oeuvre, he cannot be counted among the 'cadre philosophers', but his line of argumentation fitted into and amplified the philosophical backing for the anti-religious campaign. On the definition of 'cadre philosophers' see fn. 25.

55 Klaus, Jesuiten, Gott, Materie, 22.

56 Günther Stökl, Review of Gustav A. Wetter, Der dialektische Materialismus, Jahrbücher für Geschichte Osteuropas, 1, 1 (1953), 117.

57 Gustav A. Wetter, Der dialektische Materialismus. Seine Geschichte und sein System in der Sowjetunion (Freiburg: Herder, 1952), 586. Interestingly, Klaus found this point fitting. Klaus, Jesuiten, Gott, Materie, 272.

58 Bocheński made a similar point: 'the similarities between Thomism and Marxism-Leninism are many and sometimes very striking. ... No other contemporary philosophical schools have so much in common. ... It is a fact that the majority of studies done on Marxist Leninist philosophy have been made by Thomists - which could be accounted for by their close kinship.' Bocheński, 'Discussion: Thomism and Marxism-Leninism', Studies in Soviet Thought, 7, 2 (June 1967), 154 . 
between Marxism and religious traditions. ${ }^{59}$ Focusing on the concept of hope in Christianity and Marxism, Wendland came to the conclusion that Marxism's genealogy reached back to the 'apocalyptic visions of the end of the world in late Judaism', combining chiliastic visions in the middle ages with the German idealism of the nineteenth century and could 'therefore be seen as a 'Christian false doctrine', as a partial Christianity (Teilchristentum), which passionately latched onto one specific element of Christian hope, turned it into an absolute thus spoiling it'. ${ }^{60}$ Johannes Heinz Horn interpreted this Protestant reading of the genealogy of Marxist thought as a rhetorical strategy to brand Marxism as a 'heresy', which then can be used as a justification for a 'crusade' against its representatives. ${ }^{61}$ For Horn this crusade was ecumenical. He read the works of Wetter, Metzke, Wendland and many others together as evidence for a Christian attack against Marxism, with a 'division of labor:' neothomists seemed to attack Marxism on the front of 'the dialectics of materialism' while Protestant theologians supposedly focused on the 'history of materialism'. ${ }^{62}$

That said, while Protestant theology remained a fragmented field, neothomism seemed to be embedded in institutional and political structures that gave it clearer contours. Importantly, many neothomist authors, though not all, were Jesuits (Gustav Wetter, Josef de Vries, etc.). Georg Klaus spent an entire chapter of his book-length answer to Wetter's Dialectical Materialism on the history of the Jesuit order, casting him as a member of an organisation whose main task was 'espionage and diversion'. ${ }^{63}$ Klaus did not dwell on the fact that the other neothomist philosopher he frequently cited in his book, Josef M. Bocheński, was a Dominican and not a Jesuit, or that in France Jesuits were among the strongest critics of neothomist philosophy. Jesuit thinkers, such as Pierre Bigo, Henri Chambre or Jean-Yves Calvez looked for points of intersection between Marxism and the teachings of the Catholic Church precisely around the time Wetter was reworking his Dialectical Materialism, but while Wetter used his source analysis to develop a Catholic critique of Marxism, his colleagues built on the same texts to develop a Catholic critique of capitalism. ${ }^{64}$ Moreover, when Klaus's booklength response to Wetter's reading of dialectic materialism was published, neothomism was already nearing to its end as a privileged philosophical position within the Catholic Church. The Second Vatican Council abolished its special status in all areas, including the curriculum for priests, and rehabilitated some of its critics who had been disciplined in the 1950s for their dissent within the church hierarchy. ${ }^{65}$ If materialist philosophy had many enemies in the West from 'idealism' to 'existentialism', in 1956-7 neothomism was identified as the most dangerous of them as it seemed to possess the ability to absorb the most prominent schools and permeate them in return through 'theologisation' ${ }^{\prime 66}$ and 'clericalisation'. ${ }^{67}$ Klaus called Wetter's book no less than 'an encyclopaedia of reactionary ideas'. ${ }^{68}$

\footnotetext{
59 Norbert Kapferer cites Horn's discussion of Metzke and Wendland, somewhat confusingly, as examples for arguments against neothomism. Kapferer, Das Feindbild, 173.

60 Heinz-Dietrich Wendland, 'Christliche und kommunistische Hoffnung', Marxismusstudien, 1 (1954), 214-43, 216.

61 Johannes Heinz Horn, 'Religion und Gesellschaft. Kritik herrschender Auffassungen in der bürgerlichen Religionssoziologie', in Robert Schulz, ed., Beiträge zur Kritik der gegenwärtigen bürgerlichen Geschichtsphilosophie (Berlin: Deutscher Verlag der Wissenschaften, 1958), 155-6.

62 Günter Heyden, ed., Philosophie des Verbrechens. Gegen die Ideologie des deutschen Militarismus (Berlin: Deutscher Verlag der Wissenschaften, 1959), 337. Dieter Berger and Wolfgang Jahn, eds., Der Kreuzzug der evangelischen Akademien gegen den Marxismus (Berlin: Dietz, 1960), 8.

63 Klaus, Jesuiten, Gott, Materie, 28.

64 Pierre Bigo, Marxisme et humanism (Paris: Presses universitaires de France, 1953) or Jean-Yves Calvez La pensée de Karl Marx (Paris: Editions du Seuil, 1956).

65 Gerd-Rainer Horn, The Spirit of Vatican II. Western European Progressive Catholics in the Long Sixties (Oxford: Oxford University Press, 2015).

66 Ernst Albrecht, 'Der Neothomismus', Die deutsche Philosophie nach 1945 (Berlin: Deutscher Verlag der Wissenschaften, 1961), 35.

67 Albrecht, 'Der Neothomismus', 21.

68 Klaus, Jesuiten, Gott, Materie, 22. As the authors of the 1959 synopsis of East Germany's anti-religious campaign titled Philosophy of Crime put it: the politicians in Bonn are basically following a 'fascistic' ideology but because they are not allowed to use this term, in clever calculation ... they are reaching for an ideology that has not been so worn out by the political goals of imperialists, which appears more innocuous for the masses and which can be made easily accessible for
} 
Neither Bloch nor Wetter was interested in Christian-Marxist dialogue in the sense of the Paulus Society, or in developing 'core positions' divorced from political programs. On the contrary both Bloch and Wetter considered the overlaps they saw between Christianity and Marxism as a starting point for developing their own philosophical (and political) agendas. As East Germany was reorienting its religious politics, however, Bloch and Wetter ended up serving as two different types of cautionary tales about the dangers of conversation between ideologies, which challenged the dichotomy the SED tried to create between religion and politics. The campaigns against Bloch and the neothomists formed a curious symmetry. At the heart of both was ultimately the SED's perception of the danger of transgression: on the one side a philosopher who developed non-dogmatic Marxist philosophy based on, amongst others, his reading of the Bible, and, on the other side, neothomist philosophers reading the communist canon in order to undermine Marxist thought and to provide ideological fodder to East Germany's adversaries in the Cold War.

\section{Dialogue: Divide and Conquer}

In October 1960 Walter Ulbricht delivered a speech to the state council about a new 'socialist community of mankind' and declared that 'Christianity and the humanistic goals of socialism are not opposed to each other'. ${ }^{69}$ The radical change of tone in comparison to 1957 occurred for several reasons. First, even if the Catholic Church still resisted an official agreement with the East German state, the Protestant Church had been pressured already in 1958 into issuing a communique stating that Christians 'respected the development of socialism' and were 'fulfilling their duties as citizens'.70 The immediate background to the communique had been a curriculum reform that banned religious education at schools and the 'military chaplaincy treaty' of 1957 in West Germany. The first proved to be an effective tool of intimidation against religious actors and the second delivered an excuse to the SED to demand a declaration of loyalty from the Protestant Church. Ulbricht's speech sounded like concessions made from a position of strength and authority. Paul Verner, one of the chief architects of church policy, argued that if Christians could be convinced to believe that they could achieve their goals in a socialist state then they would also soon realise that they did not need the church as an institution. $^{71}$

At the same time Ulbricht's pronouncement also revealed weakness. The aggressive phase of 'building socialism' - the collectivisation of the countryside and the atheistic propaganda - generated a wave of emigration from East Germany, and the tone of the speech was meant as a signal of conciliation. Stating the compatibility of socialist humanism and Christianity amounted to an admission that religion was not disappearing from socialist society. The concept of the 'socialist community of mankind' was thus a hybrid creation which showcased the regime's relative strengths and weaknesses in equal measures.

Ulbricht redefined the relationship between socialism and Christianity by switching one absolute for another. If Marxism-Leninism and Christianity were supposed to be 'irreconcilable opposites' in 1957, now he argued that 'only in socialism is it possible for the two basic social tenets of Christian belief - peace and charity - to be realised'. ${ }^{72}$ Ulbricht ignored the fact that the definitions

them, namely Christianity, especially in its Catholic form. Adenauer and his followers have elevated or denigrated Catholicism, in particular in its thomist form, to the chief ideology of contemporary imperialism and militarism in West Germany'. Heyden, Philosophie des Verbrechens, 41.

69 Walter Ulbricht, Programmatische Erklärung des Vorsitzenden des Staatsrats der Deutschen Demokratischen Republik (Berlin: Dietz Verlag, 1960), 12, 22.

70 'Gemeinsame Erklärung von Vertretern der Regierung der DDR und der evangelischen Kirchen in der DDR vom 21.07.1958', in Hans-Gerhard Koch, Staat und Kirche in der DDR. Zur Entwicklung ihrer Beziehungen von 1945-1974 (Stuttgart: Verlag der evangelischen Gesellschaft, 1975), 59.

71 Quoted in epd-Dokumentation, 20 (2012), 38-53, 47.

72 Christen und Marxisten verbinden gemeinsame Ziele und Ideale. Das Gespräch des Vorsitzenden des Staatrates, Walter Ulbricht, mit einer Delegation von Theologen, kirchlichen Amtsträgern und christlichen Bürgern am 9. Februar 1961, Hefte aus Burgscheidungen (Burgscheidungen, 1961) 5. 
of 'peace' and 'charity' in the Christian tradition did not correspond to the Marxist-Leninist understanding of these concepts. Instead, he established a historical continuity: 'in socialism, which absorbs and fulfills all progressive traditions of the past, also those dreams and struggles will find their completion, which were born out of the Christian will for progress in past decades and centuries. ${ }^{73}$ The operative term in this sentence, as in the church policy of East Germany at this time, was 'progressive'. The circular logic of the argument suggested that since socialism embodied all progressive thought including those from the Christian tradition, all that socialism left out must therefore be by definition reactionary.

Ulbricht talked about 'absorption', but his speech nonetheless showcased the way the SED deployed the performance of dialogue as a strategy of struggle. Ulbricht's message of tolerance towards churches inasmuch as they supported socialism was not only pronounced, it was also staged in a meeting between Ulbricht and a delegation of church representatives on 9 February 1961. The delegation consisted of scholars, pastors, members of the Christian Democratic Party and one member of the Catholic clergy and was led by Emil Fuchs, professor of theology and a former colleague of Ernst Bloch. ${ }^{74}$ The newspapers reported at length about the meeting and printed Fuchs's speech as well as Ulbricht's response. The meeting told several stories at the same time. The head of the central committee of the SED personally talking to church representatives was a performative confirmation of a supposedly inclusive religious policy. The meeting also demonstrated Christian compliance: the delegation delivered a declaration of support for Ulbricht's October 1960 speech carrying 32,000 signatures, which were meant to reflect the opinion of the 'majority of Christians in our state. ${ }^{75}$ In a spiral of exaggeration, commentators interpreted the numbers in different ways: the official communique of the SED referred to 'millions of Christians'; Gerald Götting, the head of the Christian Democratic Party and one of the organisers of the meeting claimed that the signatures represented Christians in West Germany too.

An account of the meeting was published in a slim volume: Christians and Marxists United Through Common Goals (1961). It contained an introduction by Götting, the declaration of support and the speeches of Fuchs and Ulbricht. The publication went even further to present the meeting as a dialogue by printing a transcript of the conversation between Ulbricht and members of the delegation. Using the formulaic language of state sanctioned publications, the transcript described the tone of discussion as 'open and friendly'. ${ }^{76}$ The conversation revolved mainly around the so-called 'military chaplaincy treaty', an agreement between the Protestant Federation of Churches (Evangelische Kirche in Deutschland; EKD) and the West German government, ${ }^{77}$ and the impending conference of the Protestant church. Three years prior Ulbricht had talked about the incompatibility of Marxism-Leninism and Christianity, in the conversation with church representatives he shifted his argument: 'this is a fact: our disagreement lies not with the members of the church in West Germany but with the reactionary church leaders. ... [The basis of our disagreement] is not worldview, but the different interpretations of peace, social justice and humanism. The military chaplaincy treaty is incompatible with a desire for peace. ${ }^{78}$ A couple of sentences later, however, Ulbricht contradicted himself, at least partially, regarding worldviews as he reminded the churches rather crudely of their responsibility to support peace: 'we have two different worldviews. It is no secret and there is no question about it. I ask you a very simple question: if we do not keep the peace, how do you want to

73 Christen und Marxisten, 5.

74 Fuchs taught at the University of Leipzig and belonged to those professors who protested against Ernst Bloch's forced retirement in 1957.

75 Christen und Marxisten, 3.

76 Ibid., 19.

77 About the discussions around the military chaplaincy treaty, see Claudia Lepp, Tabu oder Einheit? Die Ost-West Gemeinschaft der evangelischen Christen und die deutsche Teilung (1945-1969) (Göttingen: Vandenhoeck \& Ruprecht, 2005), 241-55.

78 Christen und Marxisten, 20. 
represent your worldview? From six feet under? As a nuclear cadaver (Atomtote)? That is the theory of Strauß! (minister of defense in West Germany - HT).${ }^{79}$ The true irreconcilable difference lay not between socialism and religion but socialism and capitalism, Ulbricht argued: 'the rejection of peaceful coexistence of ideologies relates primarily to the conflict between capitalism and socialism and their philosophical basis. I would not want to throw Christian teachings or Christian churches in one pot with capitalism and imperialism', before repeating the main thesis of his speech from October 1960: 'the fact is that the humanistic and social goals of early Christianity and the humanistic and social goals of socialism are in accord with each other to such a degree that their coalescence seem inevitable'. ${ }^{80}$ This was a long way from 1958, when Christianity was still termed a 'philosophy of crime'.

The public performance of conversation was a departure, but it also fitted into a long-term strategy of church policy that had been in place since 1957. The so-called policy of differentiation (Differenzierungspolitik) was based on a mixture of incentives and threats, material rewards and intimidation which were aimed at splitting the churches into 'progressive' and 'reactionary' elements. ${ }^{81}$ The policy used basic methods of divide and conquer, but the same authors who marshalled the campaign against Bloch and politicised religion also provided an ideological foundation for it. They pointed out that the Protestant Church was 'deeply split' in West Germany, and that 'only a leading minority' within the church supported Konrad Adenauer's endorsement for the nuclear weapons of NATO. ${ }^{82}$ The SED considered these inner differences as a chance for East German church politics.

Ulbricht's meeting with Fuchs was the policy of differentiation put into practice. The immediate political context for the conversation, explicitly referenced in both Ulbricht's speech and the transcript of the conversation, regarded a controversial discussion about the venue of the upcoming Kirchentag. The Kirchentag, the largest meeting of Protestant laity with roots reaching back to the nineteenth century, had been taking place, with some interruptions, biannually since 1949. For the Protestant Church in the two German states, at least up until 1957, the Kirchentag was a demonstration of unity across the Iron Curtain and served as a forum for formulating the church's position on contemporary issues. ${ }^{83}$ Following the 1959 Kirchentag in Munich, the SED made clear that leading figures of the Protestant Church from West Germany would not be allowed to cross the border should the Kirchentag take place in East Germany. As plans for the upcoming 1961 Kirchentag were made, the organisers first considered West Berlin as a venue. This plan was immediately met with criticism from both East and West German church members. ${ }^{84}$ The intricate negotiations behind the scenes within the ranks of the Protestant Church and between church and state representatives go beyond the scope of this article, but by December 1960 the SED decided to use the upcoming event as a way to split the Protestant Church: a Kirchentag in West Berlin was a provocation, they argued, and suggested the organisers looked for another venue, somewhere in East Germany. ${ }^{85}$ To increase pressure on the decision makers, the Neues Deutschland published an article in the middle of January condemning West Berlin as a venue and suggesting Leipzig instead, knowing that leading members of the church from West Germany would be denied a visa to attend. ${ }^{86}$

Ulbricht's meeting with church representatives followed barely two weeks after the publication of this article. The meeting was set to coincide with the beginning of the church synod offering Ulbricht a

\footnotetext{
79 Ibid., 21.

80 Ibid., 23.

81 Schäfer, The East German State and the Catholic Church, 127.

82 Heyden, Philosophie des Verbrechens, 257.

83 Benjamin Pearson: A Divided Nation in a Divided World: The Kirchentag and the Globalization of German Protestantism from the 1950s to the 1970s, in Katharina Kunter, Annegreth Schilling, eds., Globalisierung der Kirchen. Der Ökumenische Rat der Kirchen und die Entdeckung der Dritten Welt in den 1960er und 1970er Jahren (Vandenhoeck \& Ruprecht, Göttingen 2014), 257-76.

84 Dirk Palm, “Wir sind doch Brüder!" Der evangelische Kirchentag und die deutsche Frage 1949-1961 (Göttingen: Vandenhoeck \& Ruprecht, 2002), 280.

85 Palm, "Wir sind doch Brüder!", 283.

86 'Unterredung des Staatssekretärs für Kirchenfragen mit evangelischen Bischöfen', Neues Deutschland, 12 Jan. $1961,2$.
} 
platform to make his position clear but set in scene as a gesture of open dialogue. In the following months the organising committee of the Kirchentag split over the question of whether it was more important to send a political signal by insisting on the holding West Berlin as the venue to ensure the participation of prominent members of the church (and risking that citizens of East Germany would not be allowed to attend) or to lay an emphasis on the unity of the laity and move the meeting somewhere else. ${ }^{87}$ As a compromise of sorts, the Kirchentag was held in both parts of Berlin. The hardliners within the organising committee of the Kirchentag achieved that Berlin was kept as a venue but the East German government was at least somewhat appeased as the event was not cast as a symbolic embodiment of German unification under West German aegis. Barely three weeks after the 1961 Kirchentag the Berlin Wall was erected and created new parameters both for the Protestant Church as an institution and also for the Christian-Marxist dialogue in general.

\section{Dialogue: An Old-New Method of the Ideological Adversary}

'Currently, political forces apply the buzzword dialogue to a whole slate of political and ideological debates, to attempts at establishing contact and to [various] encounters across Europe' ${ }^{88}$ The philosopher Frank Rupprecht opened a long review article in 1966 with this ominous sentence, reflecting about the most recent incarnations of Marxist-Christian dialogue. In East Germany, he argued, the real dialogue had already taken place at the end of the 1950s and since then Christians and Marxists had been working together towards building socialism. Rupprecht did not directly reference Ulbricht's speech of October 1960, but, in essence, he repeated his main arguments, not as a political programme, however, but as a depiction of reality. If the term 'dialogue' had legitimacy in East Germany at all, he argued, it was to describe the formation of a common front of Christians and socialists in the 'anti-imperialist struggle'. ${ }^{89}$ Rupprecht deemed conversations taking place beyond this frame superfluous if not outright detrimental. He was especially critical of the Second Vatican Council and the two encyclicas, Johannes XXIII's Pacem in terris (1963) and Paul VI's Ecclesiam suam (1964), which identified dialogue as a key element of the modern church. For Rupprecht, the institutionalisation of dialogue through the Pontifical Council for Promoting Christian Unity, the Secretariat for Non-Christians and the Secretariat for Non-Believers were mere political instruments for the Catholic Church. He argued that the Catholic Church's insistence on dialogue was a de facto acknowledgement of socialism's strength in Europe and was driven by the church's fear of secularisation. The time of conversation between Christianity and Marxism was long over, according to Rupprecht, and those who insisted on dialogue only prolonged the essentially inevitable disappearance of religion.

Rupprecht was responding to the Christian-Marxist dialogue as an international phenomenon that was gaining momentum in the mid-1960s through conferences in Salzburg (1965) and Herrenchiemsee (1966) but also through developments in East Germany. While in the late 1950s intellectuals loyal to the socialist regime seemingly closed ranks behind the atheist campaign, this consensus loosened up after the building of the Berlin Wall. Already in 1962 the soon-to-be head of the department for scientific atheism at the University of Jena, Olof Klohr, explored 'oppositional tendencies in Catholicism'. ${ }^{90}$ In a series of articles on the role and tasks of scientific atheism and reflecting on the Second Vatican Council, Klohr formulated two theses: 1. that socialist society was not automatically atheist and that 2. the Catholic Church was entering into a new phase, in which genuine dialogue between Marxism and Christianity would become possible. ${ }^{91}$ Klohr read the theory of evolution of the

87 Palm, "Wir sind doch Brüder!", 28.

88 Frank Rupprecht, 'Weltanschauung und Politik im Dialog zwischen katholischem Christentum und Marxismus', in Deutsche Zeitschrift für Philosophie (DZfP), 14, 1 (1966), 931.

89 Rupprecht, 'Weltanschauung und Politik', 931.

90 On the academic career of Klohr: Schuster, 'Das Postulat vom baldigen Ende der Religion', 91-102.

91 Olof Klohr, 'Probleme des wissenschaftlichen Atheismus und der atheistischen Propaganda, DZfP, 12, 2 (1964), 144; idem, 'Neue Tendenzen im Katholizismus?', DZfP, 13, 9 (1965), 1121. Similar arguments are to be found in Dieter 
French Jesuit Teilhard de Chardin and presented it as a possible bridge between Marxism and Christianity. ${ }^{92}$ Klohr practiced what he preached. As representative of East Germany he participated at the 1965 conference entitled 'Atheism' organised by the Catholic Academy in Vienna and became, in effect, a participant in the Christian-Marxist dialogue. In his report about the Vienna conference Klohr remarked enthusiastically, and in a manner that Rupprecht found naïve, that it 'was free from political anti-communism and aversion towards' East Germany. ${ }^{93}$

Even more than the Catholic Church's attempt at dialogue it was precisely such examples of participation from the Marxist side that worried Rupprecht. At the Vienna conference on atheism, Klohr stated that "Marxist atheism in its essence does not mean a "no" to religion and God, but a "yes" to the world, and a "yes" to the conscious shaping of human life. ${ }^{94}$ In Rupprecht's reading Klohr's thesis echoed the position of the Paulus Society, an organisation that had been bringing together scientists, Marxist philosophers and Protestant and Catholic theologians since the mid-1950s. Reflecting on their most recent conference, Rupprecht singled out the presentation of Lucio Lombardo Radice, professor of geometry and member of the Italian Communist Party, who argued that in Italy dialogue between Marxists and Christians has long became part of everyday life and that contemporary socialism was characterised by 'ideological pluralism'. ${ }^{95}$ Radice proposed scientific discourse as a model for the conversation between Marxists and Christians. Rupprecht found that the idea of ideological pluralism was detrimental for Marxism and did not apply to East Germany. Instead of pluralism, he argued, 'a unified humanist ideology' has emerged in East Germany, in which the differences between religion and philosophy continued to exist 'for a certain amount of time'. ${ }^{96}$ Thinking about pluralism or even atheism was counterproductive in this context, he argued, because 'a worldview does not solely consist of theses about the relationship between God and the world'. ${ }^{97}$ Basing his 1966 critique of ChristianMarxist encounters on his understanding of Christian-Marxist dialogue in East Germany in the late 1950s Rupprecht created a historical (counter-)narrative of the dialogue.

In the mid-1960s Rupprecht and Klohr represented two possible approaches to the ChristianMarxist dialogue in East Germany. By the end of the decade Rupprecht's thesis of a unified humanist ideology prevailed. Klohr's term as chair for 'scientific atheism' at the University of Jena ended abruptly in 1969 and he was transferred to the Engineering Training College in Warnemüde/ Wurstow. Here, he continued with his research on scientific atheism but in a less privileged position in the East German academic landscape. ${ }^{98}$ This reflected the actual practice of religious politics. Although the sixth congress of the Free German Trade Union Confederation declared in 1963: 'the republic needs all, all need the republic', the SED set sharp limits to the degree of autonomy it was willing to tolerate from an organisation that was not directly controlled by the state. Repression against the church as an institution continued with harrowing personal consequences for its targets. The charge of 'deviation from the tenets of Marxism Leninism under the pretext of fighting dogmatism' could still result in expulsion from the SED, loss of one's academic position or house arrest. ${ }^{99}$

Bergner, Gernot Preuss, 'Differenzierung im politischen Klerikalismus-Zur Enzyklika "Pacem in terris"', $D Z f P H, 11,10$ (1963), 1189.

92 Olof Klohr, 'Oppositionelle Strömungen im Katholizismus der Gegenwart', in DZfP, 10, 12 (1962), 1502.

93 Klohr, 'Neue Tendenzen im Katholizismus', 1123.

94 Ibid., 1123.

95 Ibid., 1129.

96 Rupprecht, 'Weltanschauung und Politik', 940.

97 Ibid., 943.

98 Atheism became 'an unloved stepchild' of East German philosophy and remained so at least until the mid-1970s. Manfred Lauerman, 'Der Atheismus-das ungeliebte Stiefkind der DDR-Philosophie', in Susanne Lanwerd, ed., Atheismus: Ideologie, Philosophie oder Mentalität? (Würzburg: Könighausen \& Neumann, 2006), 121-50. In the 1980s research into scientific atheism was conducted in addition to Klohr's department mainly at the Pedagogical College Liselotte Herrmann in Güstrow under the direction of Hans Lutter. Thiede, Dialog, 288.

99 The best illustration for this is the trial and house arrest of Robert Havemann. Robert Havemann, Ein deutscher Kommunist (Hamburg: Rowohlt, 1978). 


\section{Conclusion}

Recognising the the topos of the dialogue as a strategy of struggle in East Germany in the late 1950s and early 1960s does not result in a revision of Swidler's typology. It does, however, suggest three ways in which these case studies contribute to our overall understanding of the broader context of the history of the Christian-Marxist dialogue in Europe. On the most fundamental level, it shows the potential of the topos of the dialogue as a political instrument to create and maintain ideological boundaries. In the late 1950s the theme of dialogue as transgression connected such disparate areas of ideological conflicts in East Germany as the discursive framing of Ernst Bloch's marginalisation and the campaign against politicised theology and neothomism. It has to be noted that neither Bloch nor Wetter were interested in creating a dialogue in the sense of an open-ended conversation. Bloch read monotheistic religions as a Marxist philosopher, while Gustav Wetter read Marx as a Jesuit to build an argument against communism as an ideology. By creating historical/philosophical arguments that wove together the Marxist philosophy and the history of religion, however, they created points of contact that reverberated beyond the specific political context, and they both grew into symbolic figures of the transnational Christian-Marxist dialogue of the late 1960s. ${ }^{100}$

The East German state also deployed dialogue between Christians and Marxists as a performative strategy to divide 'progressive' and 'reactionary' elements in the church. The staging of church representatives delivering signed petitions to support the building of socialism had strong echoes of the forced declarations of loyalty of the Stalinist era. As such, it provided a contrast that representatives of the Christian-Marxist dialogue in the following years distanced themselves from. At the same time, the public staging of conversations also showcased what could be considered an inherent legitimising function of dialogue. What Ulbricht exploited as a tool of church politics presented itself as a dilemma for those who wanted to recast the dialogue as an alternative to political tactics.

Thirdly, if the first two points nuance but do not necessarily challenge Swidler's typology, the example of Olof Klohr sheds light on the potential for participation in the forae usually associated with the Christian-Marxist dialogue in the 1960s. Klohr's academic biography has much in common with participants of the dialogue from other states within the Soviet sphere of influence, many of whom came from among the ranks of philosophers and sociologists of religion, who arrived at the necessity and possibility of dialogue through their studies of religious phenomena. Klohr's articles about the Vienna conference on atheism or the oppositional tendencies within Catholicism also situate him in the broader transnational discourse about the possibility of dialogue. The abrupt dissolution of his department in Jena and his marginalisation within the academic landscape on the other hand show the state-imposed limitations on such experiments. It was not Klohr's enthusiastic response to the Second Vatican Council but Rupprecht's narrative of a dialogue that had already been completed with the development of socialist humanism in East Germany that reflected the official position of state ideology and the direction of church policy for the coming decades.

100 Both Ernst Bloch and Gustav Wetter became active participants in the unfolding transnational Christian-Marxist dialogue. Bloch's works served as an inspiration for the generation of '68 and Wetter participated at the conferences of the Paulus Society. They both remained sceptical of an open-ended dialogue between Christianity and Marxism.

Cite this article: Tóth H (2020). Dialogue as a Strategy of Struggle: Religious Politics in East Germany, $1957-1968$. Contemporary European History 29, 171-186. https://doi.org/10.1017/S0960777320000065 